JEL Classification: G34, G38, L22, P26

Keywords: Chinese Communist Party (CCP), party secretary, government intervention

\title{
Party Control in China's Listed Firms*
}

Wei YU_Finance School, Shanghai University of International Business and Economics (yu263wei@hotmail.com, yuwei@suibe.edu.cn)

\begin{abstract}
Along with state shareholding and government administration, the third source of political control of Chinese listed firms is the Chinese Communist Party (CCP). Using a unique hand-collected dataset that includes party secretary information for listed firms between 2000 and 2004, we examine the existence and power of party secretaries in companies. The party secretary is the leader of the party committee and exercises the power of the CCP at firm level. Power is assessed by examining whether the party secretary concurrently holds another key management position, such as chairman or CEO, thus allowing him or her to exert influence on the managerial decisions of the firm. We find that state-owned enterprises (SOEs) and firms with many employees are more likely to have a party secretary or a powerful party secretary than are other firms. Party secretaries are more likely to have political reliability but less professionalism than CEOs and other senior managers.
\end{abstract}

\section{Introduction}

Along with state shareholding and government administration, the third source of political control of Chinese listed firms is the Chinese Communist Party (CCP). A firm's party committee, which is commonly staffed with hand-picked executives, channels state policy into corporate practice. Morck, Yeung, and Zhao (2005) observed that the party committee has control over the board of directors and, thus, exerts actual corporate governance power. As leader of the party committee, the party secretary exercises the power of the CCP. These "bosses" have been something of a mystery in academe.

To date, most analyses of failures of governance in China's state-owned enterprises (SOEs) have focused on administrative interference by state institutions (Aharony et al., 2000; Fan et al., 2007; Sun et al., 2003). In addition, no detailed analysis of the participation and influence of CCP institutions in the governance of Chinese-listed firms has yet been conducted. The few existing studies on this important issue are primarily descriptive in nature, and their findings tend to be based on selective case studies (Tenev et al., 2002; McGregor, 2001; Dean, 2006) or survey results (Wong et al., 2004). Systematic evidence on the existence of party secretaries is scarce.

In this paper, we examine the political control of the CCP over China's enterprises using a unique hand-collected dataset that includes information about

\footnotetext{
"This paper is the first part of our dissertation. We would like to thank our dissertation committee, Professor Joseph P. H. Fan (supervisor), Professor T. J. Wong (chair), Professor Oliver M. Rui, Professor Cong Wang, Professor George Y. Yang, and Professor Stuart Gillan for their valuable suggestions and comments. We are also grateful to participants of the research workshop at the Chinese University of Hong Kong and the 8th Annual Darden International Finance Conference (Singapore Event), 2009. The author acknowledges financial support from the Leading Academic Discipline Project of Shanghai Municipal Education Commission, Project Number: 085. All errors are our own.
} 
party secretaries for listed firms between 2000 and 2004. The existence of a party secretary and the extent of his or her power over a firm's managerial decisions are used as a proxy for the CCP's influence on the enterprise. Although China's economy has recently undergone some of the most far-reaching and fundamental changes in its history, the country's political system has not adapted, and the combination of an emerging market and CCP management has resulted in conflicting goals. The party's role in the new governing institutions of the country's state-owned enterprises (SOEs) has created pronounced governance problems and may also be affecting the behavior of non-state firms.

The first set of tests investigates which types of firms are more likely to have a party secretary and, by extension, when a party secretary has more power than usual (i.e., he or she concurrently holds a key management position, such as chairman, CEO, or senior manager, in the firm). We find that SOEs and firms with a large number of employees are more likely to have a party secretary or a powerful party secretary than are other firms, which suggests that the CCP wants to maintain its power over these types of firms in order to avoid challenges to its political status as the ruling party.

The second set of tests examines the personal characteristics of party secretaries. The differing duties of a party secretary and managers (e.g., CEOs) lead to differences in their personal characteristics and career path. CEOs and managers work on the company's operational and strategic decisions, but a party secretary's major duties are to disseminate the CCP's principles, carry out the policies and resolutions of the government party in the firm, and so on. Empirical evidence shows that party secretaries are likely to have more political reliability (that is, connections) but less professionalism than other top managers and CEOs.

The arrangement of party secretaries used to be common in the Soviet bloc before 1989. Now party secretaries exist only in China, Vietnam, and some other socialist countries. This research addresses the corporate governance problems of firms in countries that are undergoing some economic reforms without the introduction of a pluralistic and democratic political system. It can contribute to the literature on firm de-politicization and to comparative studies of corporate governance and reform strategies in the socialist market economy. An understanding of these firms' characteristics will lead to a better understanding of the interdependence of economic and political reform.

The remainder of the paper proceeds as follows. Section 2 discusses the institutional background of the CCP in China and develops the research hypotheses. Section 3 introduces the data and the sample. Section 4 describes the existence of a party secretary or a powerful party secretary in a firm. Section 5 shows the party secretary's personal characteristics. Section 6 concludes the paper.

\section{Background and Hypotheses Development}

Since winning the "new democratic revolution" and founding the People's Republic of China (PRC) in 1949, the Chinese Communist Party (CCP) has been the country's ruling party. In theory, the CCP does not take the place of the government in the state's leadership system but, as the party in power, turns its ideas and policies into state laws and decisions, which are then passed by the National People's 
Congress of China through the state's legislative process. By the end of 2006, there were about 72 million CCP members in China, ${ }^{1}$ accounting for about five percent of the nation's population. It is not easy to become a CCP member. An applicant for party membership must be accepted at a general membership meeting of the party branch concerned and approved by the next higher party organization. He or she usually undergoes observation through rigorous examination by the party branch for a probationary period before being granted full membership. The examination includes whether the person can fulfill the duties of a CCP member in an organization and implement the party's basic line, principles, and policies. Party members serve in almost all types of organizations and hold key positions in government, schools, research institutes, and enterprises.

The managers of China's firms have been subject to party control since the founding of the PRC. In late 1978, the country's leadership under Deng Xiaoping introduced a number of economic reforms and started ongoing efforts to transfer firms' decision-making power from local party committees and state bureaucrats to managers (You, 1998). However, the country's political system has not adapted, because political stability and control have top priority. The gradual reform approach has generated some competitive pressure and increased the productive efficiency of some state-owned enterprises (SOEs), but it has also allowed the interference of the party and state institutions in the corporate governance of these firms to continue. The reforms implemented have not been able to disentangle party management from corporate governance.

Chinese SOEs come under the dual leadership of the state and the CCP. On the state side, the State-Owned Assets Supervision and Administration Commission (SASAC) plays an active, although by no means exclusive, role as ultimate owner. On the party side, the Organization Department selects and appoints firms' top executives, evaluates their performance, gives them incentives, and oversees their work. This constellation of monitoring and enforcement mechanisms dominated by the CCP ensures that managers at every level pay close attention to policy signals emanating from the highest reaches of the CCP.

The CCP remains the political center of SOEs and, as such, handles all political affairs, including applying party lines and policies, enforcing commitment to ideological principles, and ensuring that corporate decisions take national policies into account. It plays a pivotal role in key decisions, for example, the nomination of top executives, executive evaluation and compensation, asset acquisitions and disposals, and annual budgets. The board of directors often seems to have no more than the ability to rubber stamp big decisions (Huang and Orr, 2007).

The party may become involved in all of the major corporate decisions of SOEs by placing party cadres in the most important leadership positions, including those of the CEO and the general manager (McNally, 2002). The CCP has always placed great emphasis on the selection and appointment of cadres and on their education and training. According to this principle, the party selects party and nonparty cadres who should possess political integrity, implement the party's policies, and also have some professional competence. The ranks of the cadres usually determine the level of managerial positions they can hold. For instance, a CEO is

\footnotetext{
${ }^{1}$ Source: Statistics of the Organizing Department, Central Committee of the CCP.
} 
a one-level-higher cadre than a Chief Financial Officer (CFO) or other department manager.

According to the CCP's constitution since 2002, all types of organizations, including non-SOEs, are required to establish the primary organizations of the party if they have at least three full party members. The primary party organizations perform the party's work in the basic units of society and usually are constituted by some selected CCP members who are approved by the next higher party organization. In 2002, the 16th National Congress of the CCP inscribed the duties of the primary organizations in non-SOEs in the party constitution as a signal of its intention to strengthen its control over foreign and private enterprises. Over time, increasing numbers of private enterprises have established the primary organizations of the party, and some have hired a full-time party secretary. In this kind of political and economic institutional environment, these non-SOEs may also have to alter their operating strategies in order to show their compatibility with the policies of the dual party-government.

\subsection{Party Secretaries in China's Listed Firms}

At listed firm level, a party committee or party branch (a less powerful organization) is established by approval of the next higher party organization, usually the party committee in the parent company. If there is no higher party organization, as may be the case with certain private or foreign firms, there might be no party organization established at firm level. This may be why the CCP has been strengthening its control over these firms since 2002. The primary organizations of the CCP in listed firms report directly to the next higher level party committee in terms of vertical management. A party secretary is hired only when there is a party committee in the firm, but some firms may have only a deputy party secretary or a number of committee members. The party secretary is the leader of the party committee and exercises the power of the CCP at firm level.

The party executive in the holding company or the government owner decides on the establishment of the primary party organizations and the appointment of party representatives in listed firms. Even in SOEs, the party committee may only be established in the parent company, with the party secretary of the controlling shareholder handling the work in the listed firms. If a listed firm does not hire a full-time party secretary, then the influence of the CCP in that firm is comparatively weak, demonstrating that the parent company has chosen to lessen the direct influence of the party. Since China's adoption of a socialist market economy, the party secretary has been unable to take the place of managers or directors, although he or she can still exercise power by taking up management positions within the company, such as chairman, $\mathrm{CEO}$, or senior manager. When a party secretary is powerful, that is, he or she serves concurrently as chairman and/or CEO and has influence over the firm's managerial decisions, it is easy for him or her to exercise party control in the firm. This gives rise to our first research question: which types of firms are more likely to have a party secretary or a powerful party secretary?

SOEs are ultimately owned by central or provincial governments. Because, in reality, China has a party-government system, the CCP has a great effect on these enterprises. At the same time, because the government is run by the $\mathrm{CCP}$, the latter 
also still controls a major portion of the economy, even after the economic reforms, and its leadership has no intention of giving up that control, particularly over strategic industries such as electricity and telecommunications.

China's private sector (including both privately owned and foreign-owned firms) is developing very fast. In 2005, non-SOEs (including foreign-owned enterprises) contributed about 65 percent of the country's GDP. ${ }^{2}$ The 16 th National Congress of the CCP in 2002 inscribed the duties of the primary organizations in nonSOEs in its constitution to signal the party's intention to strengthen its level of control over foreign and private enterprises. However, the revision of the constitution also shows the comparatively weak influence of the $\mathrm{CCP}$ over these firms.

In theory, the $\mathrm{CCP}$ faces no challenges to its power as ruling party unless the one-party system is abolished. In reality, it shows a strong inclination to maintain its ideological influence over the people, obtain their political support, and avoid any type of defiance. For these reasons, the CCP is more likely to strengthen its power in firms with many employees ("voters"). Therefore, we expect that SOEs, firms with many employees, and firms in strategic industries are more likely to have a party secretary or a powerful party secretary than are other firms.

\subsection{Personal Characteristics of Party Secretaries}

The major duties of party secretaries, CEOs, and other top executives fall into two general areas: party discipline and business-oriented. The CEO and managers work on the company's operational and strategic decisions, while a party secretary's major duties are to disseminate the CCP's principles, carry out government-party policies and resolutions in the firm, and so on. Compared with the CEO and other managers in the firm, a party secretary should have different personal characteristics, talents, and career experience.

The different preferences for the choice of CEO and party secretary might lead to distinct career paths between them. Party secretaries might have worked in government or party agencies, or risen through the human resource departments, labor unions, or propaganda departments of enterprises. For CEOs and other top executives, however, business education and work experience are vitally important. Because of these different selection criteria and career paths, it is predictable that party secretaries are likely to have more political reliability and less professionalism than CEOs and other top executives.

\section{Sample Selection and Data Description}

\subsection{Sample Selection}

Our data include information about the party secretary in firms with A-shares for the years between 2000 and 2004, inclusive. Because it is not mandatory for firms to disclose their information about party secretaries, we obtained these data in a proactive manner. First, we consulted the proxy statements of the firms' annual reports and announcements in the news. Some of the proxy statements included party secretary information if the secretaries also worked as directors, executives, or super-

${ }^{2}$ October 1, 2007, Outlook Weekly, Xinhua News Agency. 
visors. If this was not the case, then we browsed the firm's website (if it had one) or performed a Google search using the key words "firm's name" + "party secretary," "firm's listing symbol" + "party secretary," "firm's stock code" + "party secretary," "chairman's name" + "party secretary," "CEO's name" + "party secretary," etc. For those firms for which we were still unable to obtain the relevant information, we called the telephone numbers listed in their financial statements. In most cases, this put us through to the staff in the office of the board secretary, most of whom kindly answered our questions about the presence of a party secretary in their firms. In the end, we were able to gather information about party secretaries for about $70 \%$ of the firms for the sample period under consideration.

Our empirical analyses require accounting numbers and data on the listing status and ownership structure of the firms, and biographical information about senior managers and directors. We obtained all of the required financial data from the CSMAR China Stock Market Financial Database. CSMAR is a widely used database in Chinese research. The data on the directors and senior managers were retrieved from the Manager Profile Database of the Wind Financial Terminal. The Wind Manager Profile Database contains detailed biographical information about executives of publicly traded firms in China. From the biographical information, we extracted the personal characteristics - including age, sex, and educational background - of the current or former government bureaucrats, CCP members, Certified Public Accountants (CPAs), and lawyers in the firm. We winsorized the top and bottom $1 \%$ of the financial variables to diminish the effect of outliers. Because of incomplete data for some of the items, the total number of observations varies across the estimation models.

\subsection{Data Description}

The sample distribution is reported in Table 1. Most of the firms have a party secretary. We obtained party secretary data for 4,104 firm-years between 2000 and 2004, which represents $68 \%$ of the total firms with A-shares in China during that period. Only $11 \%$ of the firms said that they did not have a party secretary. In those firms with party secretaries, many of the secretaries hold other management positions as well: $5 \%$ also serve as both the chairman and the CEO; $18 \%$ also serve as the chairman; $6 \%$ also serve as the CEO; and 26\% also serve as a supervisor, director, or executive (Table 1). Thus, many party secretaries have a significant affect on firm management.

In the following analysis, we delete the $30 \%$ of firms whose party secretary status was not determined, although we added those $30 \%$ missing observations in unreported sensitivity tests. With no reason to predict that these firms are any different from the others, we assume that those firms behave as other firms do and that their results are similar to the results from the other firms. The proportion of firms without a party secretary is higher in non-SOEs $(235 / 806$, or $29.2 \%$ ) than in SOEs $(330 / 2828$, or $11.6 \%)$. The industry sector classification is based on the Index of Industrial Distribution of Listed Companies, which is issued by the China Securities Regulatory Commission (CSRC). We use the one-digit industry codes, except for the manufacturing sector, for which we use two-digit codes. The manufacturing sector accounts for about $56 \%$ of the sample. 
Table 1

Panel A: Sample Distribution

This table presents the party secretary information for all the listed firms over 2000-2004.

\begin{tabular}{|c|c|c|c|c|c|c|c|c|c|c|c|c|c|}
\hline \multirow{2}{*}{\multicolumn{2}{|c|}{ Year }} & \multicolumn{2}{|c|}{2000} & \multicolumn{2}{|c|}{2001} & \multicolumn{2}{|c|}{2002} & \multicolumn{2}{|c|}{2003} & \multicolumn{2}{|c|}{2004} & \multicolumn{2}{|c|}{ total } \\
\hline & & No. & $\%$ & No. & $\%$ & No. & $\%$ & No. & $\%$ & No. & $\%$ & No. & $\%$ \\
\hline \multirow{6}{*}{ 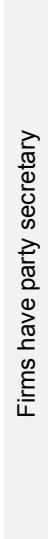 } & $\begin{array}{l}\text { No split of } \\
\text { Secretary/Chair } \\
\text {-man/CEO }\end{array}$ & 54 & 5 & 53 & 5 & 55 & 5 & 59 & 5 & 63 & 5 & 284 & 5 \\
\hline & $\begin{array}{l}\text { Party secretary } \\
\text { is chairman } \\
\text { of board }\end{array}$ & 169 & 16 & 201 & 18 & 220 & 18 & 240 & 19 & 264 & 19 & 1094 & 18 \\
\hline & $\begin{array}{l}\text { Party Secretary } \\
\text { is CEO }\end{array}$ & 70 & 7 & 73 & 6 & 70 & 6 & 72 & 6 & 78 & 6 & 363 & 6 \\
\hline & $\begin{array}{l}\text { Party Secretary } \\
\text { is the chairman } \\
\text { of supervisor } \\
\text { committee }\end{array}$ & 7 & 1 & 8 & 1 & 10 & 1 & 9 & 1 & 11 & 1 & 45 & 1 \\
\hline & $\begin{array}{l}\text { Party secretary } \\
\text { is executive, } \\
\text { director, or } \\
\text { supervisor }\end{array}$ & 262 & 25 & 288 & 25 & 303 & 25 & 325 & 26 & 320 & 23 & 1498 & 25 \\
\hline & Others & 26 & 2 & 29 & 3 & 30 & 2 & 31 & 2 & 42 & 3 & 158 & 3 \\
\hline \multicolumn{2}{|c|}{$\begin{array}{l}\text { Firms do not have } \\
\text { party secretary }\end{array}$} & 111 & 10 & 116 & 10 & 130 & 11 & 141 & 11 & 164 & 12 & 662 & 11 \\
\hline \multicolumn{2}{|c|}{$\begin{array}{l}\text { Information is not } \\
\text { available }\end{array}$} & 361 & 34 & 371 & 33 & 389 & 32 & 390 & 31 & 421 & 31 & 1932 & 32 \\
\hline \multicolumn{2}{|c|}{ Total } & 1060 & 100 & 1139 & 100 & 1207 & 100 & 1267 & 100 & 1363 & 100 & 6036 & 100 \\
\hline
\end{tabular}

Panel B: Distribution of Sample by Ownership

\begin{tabular}{lrrr}
\hline \multirow{2}{*}{ Ownership_sOE } & \multicolumn{2}{c}{ Secretary_dummy } & \multirow{2}{*}{ Total } \\
\cline { 2 - 3 } & $\mathbf{0}$ & $\mathbf{1}$ & \\
\hline 0 & 235 & 571 & 806 \\
1 & 330 & 2,493 & 2823 \\
Total & 565 & 3,064 & 3,629 \\
\hline
\end{tabular}

Note: We exclude the sample for which party secretary information and ownership type are not available.

Panel C: Sector Dstribution of the Sample

\begin{tabular}{llcc}
\hline csrc_code & Industry & Frequency & Percent \\
\hline A & Agriculture & 71 & 1.73 \\
B & Mining & 55 & 1.34 \\
C & Manufacturing & 2,311 & 56.31 \\
C0 & Food, Beverage & 176 & 4.29 \\
C1 & Textile, Apparel, Leather & 154 & 3.75 \\
C2 & Wood Products & 8 & 0.19 \\
C3 & Paper, Printing & 74 & 1.80 \\
C4 & Petroleum, Chemical Products, Rubber, Plastics & 450 & 10.96 \\
C5 & Electronic Equipment & 129 & 3.14 \\
C6 & Metal, Nonmetallic Mineral Products & 367 & 8.94 \\
\hline
\end{tabular}




\begin{tabular}{llrc}
\hline csrc_code & Industry & Frequency & Percent \\
\hline C7 & Machinery, Equipment, Meters & 613 & 14.94 \\
C8 & Medicine, Biological Products & 287 & 6.99 \\
C9 & Other Manufacturing & 53 & 1.29 \\
D & Electricity, Gas, Water Supply & 163 & 3.97 \\
E & Construction & 67 & 1.63 \\
F & Transportation \& Storage & 187 & 4.56 \\
G & Information, Technology & 215 & 5.24 \\
H & Wholesale and Retail Trade & 297 & 7.24 \\
I & Finance and Insurance & 30 & 0.73 \\
J & Real Estate & 150 & 3.65 \\
K & Social Services & 96 & 2.34 \\
L & Transmission, Culture & 33 & 0.80 \\
M & Conglomerate & 429 & 10.45 \\
\hline & Total & 4,104 & 100 \\
\hline
\end{tabular}

Notes: The classification is based on Index of Industrial Distribution of List Companies, Issued by the CSRC on April 3rd, 2001. We exclude the sample whose party secretary information is not available and whose industry group we cannot identify.

\section{Table 2 Summary Statistics}

\section{Panel A: Financial Numbers}

Panel A reports the mean and median statistics of the financial characteristics for the sample during 2000-2004. The table also reports the statistics for two subsamples of firms sorted by whether or not they have a party secretary. The definitions of the variables are given in Appendix A. Test statistics of the differences in the mean and median are provided.

\begin{tabular}{lcccc}
\hline \multirow{2}{*}{ Variable } & All & $\begin{array}{c}\text { Firm without } \\
\text { Party Secretary }\end{array}$ & $\begin{array}{c}\text { Firm with Party } \\
\text { Secretary }\end{array}$ & $\begin{array}{c}\text { P-value } \\
\text { (difference) }\end{array}$ \\
\cline { 2 - 5 } & $\mathbf{( 1 )}$ & $\mathbf{( 2 )}$ & $\mathbf{( 3 )}$ & $\mathbf{( 4 )}$ \\
\hline Log_totalassets & 21.1285 & 20.7596 & 21.1994 & $\mathbf{0 . 0 0 0 0}$ \\
& $(20.9987)$ & $(20.6285)$ & $(21.0678)$ & $\mathbf{0 . 0 0 0 0}$ \\
& {$[4104]$} & {$[662]$} & {$[3442]$} & \\
Log_employees & 7.3694 & 6.7368 & 7.4911 & $\mathbf{0 . 0 0 0 0}$ \\
& $(7.4281)$ & $(6.8357)$ & $(7.5299)$ & $\mathbf{0 . 0 0 0 0}$ \\
Leverage & {$[4104]$} & {$[662]$} & {$[3336]$} & \\
& 0.2458 & 0.2530 & 0.2444 & 0.2285 \\
& $(0.2302)$ & $(0.2256)$ & $(0.2306)$ & 0.8652 \\
Log_sales & {$[4104]$} & {$[662]$} & {$[3442]$} & \\
& 20.3259 & 19.7208 & 20.4422 & $\mathbf{0 . 0 0 0 0}$ \\
& $(20.2535)$ & $(19.6956)$ & $(20.3322)$ & $\mathbf{0 . 0 0 0 0}$ \\
Log_sales_per_employee & {$[4104]$} & {$[662]$} & {$[3442]$} & \\
& 12.9564 & 12.9840 & 12.9511 & 0.5847 \\
& $(12.8524)$ & $(12.9032)$ & $(12.8317)$ & 0.2347 \\
& {$[4104]$} & {$[662]$} & {$[3442]$} & \\
\hline
\end{tabular}


Panel B: Party Secretary, CEO, Senior Managers and Directors' Characteristics

Panel B reports the mean statistics of the characteristics of party secretaries, CEOs, senior managers and directors during 2000-2004. The definitions of the variables are given in Appendix A. Test statistics of the differences in the mean are provided.

\begin{tabular}{|c|c|c|c|c|c|c|c|c|}
\hline & \multicolumn{2}{|c|}{$\begin{array}{c}\text { Party } \\
\text { Secretary }\end{array}$} & \multicolumn{2}{|c|}{ CEO } & \multirow{2}{*}{$\begin{array}{l}\text { P-value for } \\
\text { difference in } \\
\text { mean (Party } \\
\text { Secretary } \\
\text { Versus CEO) }\end{array}$} & \multicolumn{2}{|c|}{$\begin{array}{c}\text { Senior } \\
\text { Managers and } \\
\text { Directors }\end{array}$} & \multirow{2}{*}{$\begin{array}{c}\text { P-value for } \\
\text { difference in } \\
\text { mean (Party } \\
\text { Secretary Versus } \\
\text { Senior Managers } \\
\text { and Directors) }\end{array}$} \\
\hline & Mean & $\mathbf{N}$ & Mean & $\mathbf{N}$ & & Mean & $\mathbf{N}$ & \\
\hline Woman & 0.078 & 3314 & 0.042 & 5896 & 0.0000 & 0.102 & 101252 & 0.0000 \\
\hline Age & 49.476 & 3301 & 44.709 & 5843 & 0.0000 & 45.653 & 99463 & 0.0000 \\
\hline Education & 2.024 & 3223 & 2.159 & 5689 & 0.0000 & 2.082 & 94514 & 0.0004 \\
\hline CPA & 0.002 & 3329 & 0.007 & 5875 & 0.0000 & 0.048 & 99411 & 0.0000 \\
\hline Lawyer & 0.004 & 3329 & 0.004 & 5875 & 0.8142 & 0.020 & 99411 & 0.0000 \\
\hline CCP member & 1 & 3442 & 0.403 & 5875 & 0.0000 & 0.328 & 99411 & 0.0000 \\
\hline $\begin{array}{l}\text { Current or ex- } \\
\text { government } \\
\text { bureaucrats }\end{array}$ & 0.427 & 3329 & 0.312 & 5875 & 0.0000 & 0.333 & 99411 & 0.0000 \\
\hline
\end{tabular}

Table 2 presents the summary statistics of the financial numbers in the sample firms, both as a group and as classified by their party secretary status. The definitions of the variables used in this paper are listed in Appendix A. Table 2 shows that the firms with a party secretary are larger in terms of both total assets and the number of employees. However, there is no significant difference between the two groups in terms of the amount of leverage. As for the labor productivity measures, there is no significant difference between the groups in sales per employee, although firms with a party secretary have more sales than those without one, which is consistent with the results for total assets and the number of employees.

\section{The Presence of a Party Secretary in a Firm}

We test for the existence of a party secretary and powerful party secretary using a logistic model or ordered logistic model of the following form:

$$
\begin{aligned}
& \text { Logistic(Secretary_dummy) }= \\
& =f\left(\begin{array}{c}
\alpha_{0}+\beta_{1} \text { Ownership_SOE }+\beta_{2} \text { Strategic industry }+ \\
+\beta_{3} \log _{-} \text {employees }+\sum \beta_{i} \text { Control Variables }+\varepsilon_{i}
\end{array}\right) \\
& \text { Ordered Logistic(Secretary_important) }= \\
& =f\left(\begin{array}{c}
\alpha_{0}+\beta_{1} \text { Ownership_SOE }+\beta_{2} \text { Strategic industry }+ \\
+\beta_{3} \log _{-} \text {employees }+\sum \beta_{i} \text { ControlVariables }+\varepsilon_{i}
\end{array}\right)
\end{aligned}
$$

We use both the logistic and ordered logistic model to test for the existence of a party secretary and a powerful party secretary in the firms. One of the dependent variables, Secretary_dummy, is a binary dummy variable that is equal to 1 if a firm 
has a party secretary, and 0 otherwise. Another dependent variable, Secretary important, is an ordinal number equal to 0 if a firm has no party secretary; to 1 if the party secretary holds no other position in the firm; to 2 if he or she is also a director, senior manager, or supervisor; to 3 if he or she is also the chairman or CEO; and to 4 if the party secretary is also both the chairman and the CEO. Secretary_important measures the power the party secretary wields in the firm's management. The underlying assumption is that his or her level of power will increase if he or she concurrently holds another important management position in the firm. The independent variables include Ownership_SOE, Strategic industry, and log of Number of employees. In addition, we attempt to control for certain other factors by using control variables, $\log _{\text {_totalassets, }} \mathrm{BH}_{-}$list , and the fraction of shares held by the largest shareholder. In China, firms may issue A-shares, B-shares, or $\mathrm{H}$-shares individually or jointly. A-shares are issued on the Shanghai or Shenzhen Stock Exchange and are traded by local investors. B-shares are also issued on the Shanghai or Shenzhen Stock Exchange but, before 2000, were traded only by foreign investors. ${ }^{3} \mathrm{H}$-shares are issued on the Hong Kong Stock Exchange and traded by global investors. This study focuses on firms with A-shares, although some of the firms in the sample also issued B- or H-shares at the same time. The participation of foreign investors may have a negative effect on the existence of a party secretary or powerful party secretary. Industry and year dummies are included in all of the regression models.

In general, it is likely that, because of local economic, political, and cultural factors, firms within the same geographical context will be more like each other than like those in other municipalities (Fan et al., 2007). Therefore, we include a regional dummy variable to categorize the firms based on the provincial-level location of their headquarters. Because we use panel data, we run the regression with and without controlling for firm-cluster effects. In the model without this control, we estimate the standard errors using Huber-White sandwich estimators, which take into account the issues surrounding heterogeneity.

Table 3 Panel $A$ reports the results of the logistic and ordered logistic regressions to determine whether firms have a party secretary or a powerful party secretary. The dependent variable in Models (1) and (2) is secretary_dummy, and both the coefficients and the marginal effects are presented. As expected, the coefficients of ownership_SOE and log _employees are significantly positive, which suggests that SOEs and firms with many employees are more likely to have a party secretary. However, the coefficient of strategic_industry is insignificant, although it has a positive sign. Models (3) and (4) use secretary_important as the dependent variable, and the results are generally consistent with those of Models (1) and (2). However, in Models (3) and (4), the coefficient of log_totalassets becomes insignificant. Compared with the assets measure (log_totalassets), "voters" seem to be a more important consideration for the CCP. Surprisingly, foreign investors have no obvious influence.

We perform some robustness tests in Table 3 Panel $B$ and consider two alternative explanations for these results. One explanation is that these firms have a full-time party secretary simply because they have many party members; the number

${ }^{3}$ After 2000, local investors with foreign currency could also trade B-shares. 
Table 3 The Existence of a Party Secretary or a Powerful Party Secretary

Panel A:

Panel A reports the regression results for the existence of a party secretary or a powerful party secretary. The variable definitions are listed in Appendix A. Due to incomplete data for some items, the total number of observations varies across the estimation models.

\begin{tabular}{|c|c|c|c|c|c|c|}
\hline & \multicolumn{4}{|c|}{ Logit Model: Secretary_dummy $(0,1)$} & \multicolumn{2}{|c|}{$\begin{array}{l}\text { Ordered Logit Model: } \\
\text { Secretary_Important }\end{array}$} \\
\hline & \multicolumn{2}{|c|}{ (1) } & \multicolumn{2}{|c|}{ (2) } & \multirow{2}{*}{$\begin{array}{c}\text { (3) } \\
\text { Coefficient }\end{array}$} & \multirow{2}{*}{$\begin{array}{c}\text { (4) } \\
\text { Coefficient }\end{array}$} \\
\hline & Coefficient & $\begin{array}{c}\text { Marginal } \\
\text { Effect }\end{array}$ & Coefficient & $\begin{array}{l}\text { Marginal } \\
\text { Effect }\end{array}$ & & \\
\hline \multirow[t]{2}{*}{ ownership_SOE } & $1.118^{* \star \star}$ & $0.155^{\star \star \star}$ & $1.055^{\star \star \star}$ & $0.139^{* \star *}$ & $0.644^{\star \star *}$ & $0.627^{* * *}$ \\
\hline & $(0.000)$ & $(0.000)$ & $(0.000)$ & $(0.000)$ & $(0.000)$ & $(0.002)$ \\
\hline \multirow[t]{2}{*}{ strategic_industry } & 1.057 & 0.084 & 0.546 & 0.048 & 0.636 & 0.209 \\
\hline & $(0.336)$ & $(0.177)$ & $(0.655)$ & $(0.591)$ & $(0.218)$ & $(0.735)$ \\
\hline \multirow[t]{2}{*}{ log_employees } & $0.351^{* * *}$ & $0.038^{* * *}$ & $0.373^{* * *}$ & $0.039^{* * *}$ & $0.121^{*}$ & $0.116^{* *}$ \\
\hline & $(0.000)$ & $(0.000)$ & $(0.000)$ & $(0.000)$ & $(0.083)$ & $(0.049)$ \\
\hline \multirow[t]{2}{*}{ bh_list } & -0.239 & -0.028 & 0.055 & 0.005 & -0.541 & -0.488 \\
\hline & $(0.813)$ & $(0.828)$ & $(0.957)$ & $(0.956)$ & $(0.113)$ & $(0.139)$ \\
\hline \multirow[t]{2}{*}{ ownership_percent } & -0.004 & -0.0004 & -0.005 & -0.0005 & -0.006 & -0.004 \\
\hline & $(0.529)$ & $(0.526)$ & $(0.428)$ & $(0.429)$ & $(0.114)$ & $(0.348)$ \\
\hline \multirow[t]{2}{*}{ log_totalassets } & $0.324^{\star \star \star}$ & $0.035^{\star \star *}$ & $0.271^{\star *}$ & $0.028^{\star \star *}$ & 0.090 & 0.085 \\
\hline & $(0.006)$ & $(0.008)$ & $(0.048)$ & $(0.046)$ & $(0.307)$ & $(0.263)$ \\
\hline \multirow[t]{2}{*}{ Constant } & $-9.971^{* \star *}$ & & $-10.729^{\star \star \star}$ & & & \\
\hline & $(0.000)$ & & $(0.000)$ & & & \\
\hline Year Dummy & Yes & & Yes & & Yes & Yes \\
\hline Industry Dummy & Yes & & Yes & & Yes & Yes \\
\hline Region Dummy & No & & Yes & & No & Yes \\
\hline Control for Cluster & Region & & Firm & & Region & Firm \\
\hline Observations & 3549 & & 3327 & & 3628 & 3567 \\
\hline Pseudo $R^{2}$ & 0.1286 & & 0.1855 & & 0.0257 & 0.0474 \\
\hline
\end{tabular}

Notes: Robust $p$-values in parentheses. ${ }^{*}$ significant at $10 \%$; ${ }^{* *}$ significant at $5 \% ;{ }^{* * *}$ significant at $1 \%$.

of CCP members in a firm is proportional to the number of employees hired. To rule out this possibility, we add the interaction terms of log_employees and ownership $S O E$ in Models (1) and (2). If SOEs are more likely to hire party member employees and to have a high percentage of CCP members, then the coefficients on these interaction terms should be positive. However, these coefficients are negative and significant in Model (2). Therefore, in a sense, we can rule out this explanation. Another concern is the reverse causality that the firms with a party secretary are more likely to hire excess employees. In Models (3) and (4), we use the industry-level number of employees to replace our measure of employees because an industry-level measure is less likely to be affected by the presence of a party secretary in a firm. The coefficients on the industry-level employee numbers in the two determinant models remain significantly positive. 


\section{Panel B: Robust Tests}

Panel B reports reports the results for the robustness tests. In Models (1) and (2), we add the interaction terms of log_employees and ownership_SOE. In Models (3) and (4), we use the industry-level employee number to replace the firm level.

\begin{tabular}{|c|c|c|c|c|}
\hline & \multicolumn{2}{|l|}{ (1) } & \multirow{2}{*}{$\frac{(3)}{\text { secretary_dummy }}$} & \multirow{2}{*}{$\begin{array}{c}\text { (4) } \\
\text { secretary_important }\end{array}$} \\
\hline & secretary_dummy & secretary_important & & \\
\hline \multirow[t]{2}{*}{ ownership_SOE } & $2.360^{*}$ & $3.762^{* * *}$ & $1.077^{* * *}$ & $0.683^{\star * *}$ \\
\hline & $(0.051)$ & $(0.000)$ & $(0.000)$ & $(0.001)$ \\
\hline \multirow[t]{2}{*}{ log_employees } & $0.501^{\star * *}$ & $0.458^{\star * *}$ & & \\
\hline & $(0.001)$ & $(0.000)$ & & \\
\hline \multirow[t]{2}{*}{$\begin{array}{l}\text { median_employee } \\
\text { number }\end{array}$} & & & & \\
\hline & & & $(0.035)$ & $(0.020)$ \\
\hline \multirow{2}{*}{$\begin{array}{l}\text { log_employees } \\
\text { *ownership_SOE }\end{array}$} & -0.190 & $-0.437^{* * *}$ & & \\
\hline & $(0.280)$ & $(0.001)$ & & \\
\hline \multirow[t]{2}{*}{ strategic_industry } & 0.508 & 0.088 & 0.164 & 0.083 \\
\hline & $(0.688)$ & $(0.887)$ & $(0.695)$ & $(0.710)$ \\
\hline \multirow[t]{2}{*}{ bh_list } & 0.128 & -0.349 & 0.341 & -0.455 \\
\hline & $(0.905)$ & $(0.307)$ & $(0.711)$ & $(0.169)$ \\
\hline \multirow[t]{2}{*}{ ownership_percent } & -0.005 & -0.003 & -0.005 & -0.004 \\
\hline & $(0.466)$ & $(0.481)$ & $(0.433)$ & $(0.310)$ \\
\hline \multirow[t]{2}{*}{ log_totalassets } & $0.268^{*}$ & 0.083 & $0.458^{* * *}$ & $0.167^{\star *}$ \\
\hline & $(0.052)$ & $(0.271)$ & $(0.000)$ & $(0.012)$ \\
\hline \multirow[t]{2}{*}{ Constant } & $-11.618^{\star * *}$ & & $-15.382^{* * *}$ & \\
\hline & $(0.000)$ & & $(0.000)$ & \\
\hline Year Dummy & Yes & Yes & Yes & Yes \\
\hline Industry Dummy & Yes & Yes & No & No \\
\hline Region Dummy & Yes & Yes & Yes & Yes \\
\hline Control for Cluster & Firm & Firm & Firm & Firm \\
\hline Observations & 3327 & 3567 & 3345 & 3567 \\
\hline Pseudo $R^{2}$ & 0.1869 & 0.0524 & 0.128 & 0.037 \\
\hline
\end{tabular}

Notes: Robust $p$-values in parentheses. ${ }^{*}$ significant at $10 \%$; ${ }^{* *}$ significant at $5 \%$; ${ }^{* * *}$ significant at $1 \%$.

In addition, we run the regression by separating the sample into SOE and nonSOE firms in the unreported sensitivity test and obtain similar results in both SOE and non-SOE firms, except that the coefficients on strategic industry are significantly positive in the regression of non-SOE firms.

In summary, SOEs and firms with many employees are more likely to have a party secretary or a powerful party secretary than are other firms. However, we do not find significant results regarding whether strategic industries are likely to have a party secretary. But the empirical results cannot rule out the reverse causality that a firm with a party secretary or powerful party secretary is more likely to hire excess employees. 


\section{Table 4 Party Secretary's Personal Characteristics}

Table 4 reports the results for what type of person is more likely to be a party secretary. The dependent variable is party_secretary, which equals 1 if the person is a party secretary and zero otherwise. Personal characteristics are included as independent variables. In column (1), the sample includes all party secretaries, managers, and directors. In column (2), the sample only includes party secretaries and CEOs. The definitions of the variables are listed in Appendix A.

\begin{tabular}{|c|c|c|}
\hline & \multicolumn{2}{|c|}{$\begin{array}{l}\text { Logit Model: Party secretary } \\
\qquad(0,1)\end{array}$} \\
\hline & (1) & (2) \\
\hline \multirow{2}{*}{$\begin{array}{l}\text { Current or ex-government } \\
\text { bureaucrats }\end{array}$} & $0.280^{* * *}$ & $0.443^{* * *}$ \\
\hline & $(0.000)$ & $(0.000)$ \\
\hline \multirow[t]{2}{*}{ Age } & $0.044^{\star \star *}$ & $0.097^{\star \star *}$ \\
\hline & $(0.000)$ & $(0.000)$ \\
\hline \multirow[t]{2}{*}{ CPA } & $-3.135^{\star * *}$ & -1.666 \\
\hline & $(0.000)$ & $(0.100)$ \\
\hline \multirow[t]{2}{*}{ Lawyer } & $-1.487^{\star * *}$ & 0.465 \\
\hline & $(0.008)$ & $(0.432)$ \\
\hline \multirow[t]{2}{*}{ Education } & 0.040 & 0.090 \\
\hline & $(0.289)$ & $(0.101)$ \\
\hline \multirow[t]{2}{*}{ Woman } & -0.171 & $0.660^{* \star *}$ \\
\hline & $(0.218)$ & $(0.001)$ \\
\hline \multirow[t]{2}{*}{ Constant } & $-5.535^{\star \star \star}$ & $-5.594^{\star \star *}$ \\
\hline & $(0.000)$ & $(0.000)$ \\
\hline Year Dummy & Yes & Yes \\
\hline Control for Cluster & Individual & Individual \\
\hline Observations & 97030 & 8871 \\
\hline Pseudo $R^{2}$ & 0.0329 & 0.0888 \\
\hline
\end{tabular}

Notes: Robust $p$-values in parentheses. * significant at $10 \%$; ${ }^{* *}$ significant at $5 \%$; ${ }^{* * *}$ significant at $1 \%$.

\section{Personal Characteristics of Party Secretaries} secretaries:

We use the following model to study the personal characteristics of party

$$
\begin{aligned}
& \text { Logistic (Party_secretary) }= \\
& =f\left(\begin{array}{c}
\alpha_{0}+\beta_{1} \text { Current or ex }- \text { government bureacrats }+ \\
\quad+\beta_{2} \text { Age }+\beta_{3} \text { CPA }+\beta_{4} \text { Lawyer }+\beta_{5} \text { Education }+\beta_{6} \text { Woman }+\varepsilon_{i}
\end{array}\right)
\end{aligned}
$$

We use the logistic model to test for the different personal characteristics between party secretary, CEO, and other top executives. Our sample includes party secretaries, managers, and directors in Chinese listed firms from 2000 to 2004. The dependent variable Party_secretary is a binary dummy variable that is equal to 1 if an individual is a party secretary, and 0 otherwise. The independent variables measure the personal characteristics, including current or ex-government bureaucrat, age, Certified Public Accountant (CPA), lawyer, education, and woman. The defini- 
tions of the variables are listed in Appendix A. Because we use panel data, we run the regression with year dummies and control for individual-cluster effects.

Table 2 Panel $B$ shows that the party secretary is less professional and more politically connected than are CEOs and other senior managers.

Table 4 reports the regression results on the association between an individual's position and his/her personal characteristics. Consistent with our prediction, party secretaries are more likely to be persons with political connections who are less professional than are CEOs and other senior managers. However, as the database only includes managers and directors in the listed firms, the data may be incomplete and partially observed. The results should be interpreted cautiously.

\section{Conclusion}

This study analyzes the Communist Party's political control over China's enterprises. We examine which types of firms are more likely to have a party secretary and, by extension, when that party secretary has more power by holding a key management position, such as chairman or CEO. We also study the personal characteristics of party secretaries.

We find that SOEs and firms with many employees are more likely to have a party secretary and a powerful party secretary than are other firms. Party secretaries are likely to have more political reliability but less professionalism than CEOs and other senior managers.

These results have several implications for the study of government intervention in less developed countries, including China. First, we investigate the third source of political control in China's listed firms: the CCP (the other two being state shareholding and government administration). To date, no other detailed analyses of CCP institutions in the governance of these firms have been carried out, so this research is the only one to study in detail the influence of party secretaries in Chinese enterprises and to be supported by empirical evidence. Second, as long as politicians and bureaucrats enjoy unchallengeable political authority, the high political costs will have an effect on the behavior of both SOEs and non-SOEs.

There are at least two caveats with regard to the interpretation of this study's findings. The evidence is based on one country, so it may not be applicable to others. This limitation may be particularly severe because China is unique in many respects, and prior research has found that existing theories are often unable to explain many Chinese economic phenomena (Allen, 2005). However, China has become a formidable force in the world's economy, and understanding its successes and failures in the face of economic reform without the introduction of a pluralistic and democratic political system should help us understand the interdependence of economic and political reform. Second, caution should be exercised when interpreting the results because of data limitations and possible reverse causality. 


\section{Appendix A}

This table provides the definitions of the variables employed in the study.

\begin{tabular}{|c|c|}
\hline Variable & Definition \\
\hline secretary_dummy & a dummy variable: 1 if a firm has party secretary; zero otherwise \\
\hline secretary_important & $\begin{array}{l}\text { an ordered variable: } 0 \text { if a firm has no party secretary; } 1 \text { if the party } \\
\text { secretary holds no other position in the firm; } 2 \text { if the party secretary is } \\
\text { also a director, senior manager, or supervisor; } 3 \text { if the party secretary } \\
\text { is also the chairman or CEO; } 4 \text { if the party secretary is also } \\
\text { the chairman and CEO }\end{array}$ \\
\hline ownership_SOE & $\begin{array}{l}\text { a dummy variable: } 1 \text { if the ultimate owner is a government agency or } \\
\text { state-owned enterprise; zero otherwise }\end{array}$ \\
\hline strategic_industry & $\begin{array}{l}\text { a dummy variable: } 1 \text { if the firm belongs to the following industry: } \\
\text { "B01" Coal Mining; "B03" Oil and Gas Extraction; "D01" Electric, Gas, } \\
\text { \& Sanitary Services; "F01" Railroad Transportation; "I01" Depository } \\
\text { Insitutions; "I21" Security \& Commodity Brokers, Dealers, Exchanges } \\
\text { \& Services; "I31" Trusts, "J01" Real estate and Construction, } \\
\text { "K01" Utilities Services, "L10" Media(CSRC industry } \\
\text { Classification);0 otherwise }\end{array}$ \\
\hline log_employees & log of employees' number at firm \\
\hline bh_list & a dummy variable : 1 if a firm also issue $\mathrm{B}$ - or $\mathrm{H}$ - shares; 0 otherwise \\
\hline ownership_percent & ownership percent of the largest shareholder \\
\hline log_totalassets & log of total assets \\
\hline median_employee_number & Log industry median level of number of employees \\
\hline log_sales & $\log$ of sales \\
\hline log_sales_per_employee & $\log ($ sales/number of employees) \\
\hline Leverage & Total liability/total assets at year $t$ \\
\hline $\begin{array}{l}\text { current or ex-government } \\
\text { bureaucrats }\end{array}$ & $\begin{array}{l}\text { a dummy variable: } 1 \text { if the person is current or former government } \\
\text { bureaucrat; zero otherwise }\end{array}$ \\
\hline CCP member & $\begin{array}{l}\text { a dummy variable: } 1 \text { if the person is a communist party member; zero } \\
\text { otherwise }\end{array}$ \\
\hline age & the person's age \\
\hline CPA & $\begin{array}{l}\text { a dummy variable: } 1 \text { if the person is or was a Certified Public } \\
\text { Accountant (CPA); zero otherwise }\end{array}$ \\
\hline lawyer & a dummy variable: 1 if the person is or was lawyer; zero otherwise \\
\hline education & $\begin{array}{l}\text { an ordered variable: } 4 \text { equals a doctoral degree, } 3 \text { a master's degree, } \\
2 \text { a university degree, } 1 \text { a junior college degree, and } 0 \text { below junior } \\
\text { college }\end{array}$ \\
\hline woman & a dummy variable: 1 if the person is woman; zero otherwise \\
\hline party_secretary & $\begin{array}{l}\text { a dummy variable: } 1 \text { if the person is the party secretary; zero } \\
\text { otherwise }\end{array}$ \\
\hline
\end{tabular}




\section{REFERENCES}

Agrawal A, Knoeber CR (2001): Do some outsider directors play a political role? Journal of Law and Economics, 44:179-199.

Aharony J, Lee J, Wong TJ (2000): Financial packaging of IPO firms in China. Journal of Accounting Research, 38:103-126.

Allen F, Qian J, Qian M (2005): Law, finance, and economic growth in China. Journal of Financial Economics, 77(1):57-116.

Dean J (2006): U.S. financier helps a chairman shake China Inc. The Wall Street Journal, September 29:A1.

Fan PHJ, Wong TJ, Zhang TY (2007): Politically-connected CEOs, corporate governance and postIPO performance of China's partially privatized firms. Journal of Financial Economics, 84(2): $330-357$.

Huang RH, Orr G (2007): China's state-owned enterprises: Board governance and the Communist Party. The Mckinsey Quarterly, 1:108-111.

McGregor R (2001): The little red book of business in China. London Financial Times, 8 July.

McNally C (2002): Strange bedfellows: Communist party institutions and new governance mechanisms in Chinese state holding corporations. Business and Politics, 4(1):91-115.

Morck R, Yeung B, Zhao M (2005): China's lucky corporate governance. Peking University Business Forum.

Shih VC (2008): Factions and Finance in China: Elite Conflict and Inflation. Cambridge University Press.

Sun Q, Tong W, Tong J (2003): China share issue privatization: The extent of its success. Journal of Financial Economics, 70:183-222.

Tenev S, Zhang C (2002): Corporate Governance and Enterprise Reform in China. Building the Institutions of Modern Markets. Washington, DC: World Bank and the International Finance Corporation.

Wong SML, Opper S, Hu R (2004): Shareholding structure, depoliticization and firm performance: Lessons from China's listed firms. Economics of Transition, 12(1):29-66.

You J (1998): China's Enterprise Reform: Changing State/Society Relations After Mao. London, Routledge. 